\title{
Epidemiology, surveillance and control of infectious diseases in the European overseas countries and territories, 2011
}

J Jones ${ }^{1}$, M Gastellu-Etchegorry², F K Stenz ${ }^{3}$, C Baudon ${ }^{1}$, S J Bloem ${ }^{4}$, M Bondonneau $^{5}$, S Cohuet ${ }^{1}$, R Diggle ${ }^{6}$, R W Ewing ${ }^{7}$, I Gerstenbluth $^{8}$, J P Grangeon ${ }^{9}$, K Kumar Alla ${ }^{10}$, G Lajoinie ${ }^{11}$, M Tromp ${ }^{12}$, T Tumahai ${ }^{13}$, J F Yvon ${ }^{14}$, C M Swaan ${ }^{15}$, C M Gossner (celine. gossner@ecdc.europa.eu $)^{16}$

1. Health Protection Agency (HPA), London, United Kingdom

2. French Institute for Public Health Surveillance (Institut de Veille Sanitaire, InVS), Saint Maurice, France

3. National Board of Health, Nuuk, Greenland

4. Public health and social service department, Jamestown, St Helena

5. Caisse de prévoyance sociale, Saint-Pierre, Saint Pierre and Miquelon

6. Falkland Islands health service, Stanley, Falkland Islands

7. Ministry of health, Grand Turk, Turks and Caicos Islands

8. Ministry of Health, Willemstad, Curaçao

9. Direction des affaires sanitaires et sociales de la Nouvelle-Calédonie, Nouméa, New-Caledonia

10. Ministry of health, environment, youth, sport and culture, George Town, Cayman Islands

11. Direction des affaires sanitaires et sociales de Mayotte, Mamoudzou, Mayotte, France

12. Department of public health, Oranjestad, Aruba

13. Direction de la santé de Polynésie Française, Papeete, French Polynesia

14. Agence de santé de Wallis et Futuna, Mata'Utu, Wallis and Futuna

15. National Institute for Public Health and the Environment (RIVM), Bilthoven, the Netherlands

16. European Centre for Disease Prevention and Control (ECDC), Stockholm, Sweden

Citation style for this article:

Jones J, Gastellu-Etchegorry M, Stenz FK, Baudon C, Bloem SJ, Bondonneau M, Cohuet S, Diggle R, Ewing RW, Gerstenbluth I, Grangeon JP, Kumar Alla K, Lajoinie G, Tromp M, Tumahai T, Yvon JF, Swaan CM, Gossner CM. Epidemiology, surveillance and control of infectious diseases in the European overseas countries and territories, 2011. Euro Surveill. 2011;16(29):pii=19923. Available online: http://www.eurosurveillance.org/ViewArticle.aspx?Articleld=19923

The 25 European overseas countries and territories (OCTs) are closely associated with the European Union (EU) through the four related UE Member States: Denmark, France, the Netherlands and the United Kingdom. In 2008 and 2009, these four EU Member States, in association with the European Centre for Disease Prevention and Control (ECDC), reviewed the OCTs' needs, with the objectives of documenting their capacity to prevent and respond to infectious diseases outbreaks, and identifying deficiencies. This Euroroundup is based on the review's main findings, and presents an overview of the OCTs' geography and epidemiology, briefly introduces the legal basis on which they are linked to the EU and describes the surveillance and infectious disease response systems. As a result of their diversity the OCTs have heterogeneous epidemiological profiles. A common factor, however, is that the main burden of disease is non-communicable. Nevertheless, OCTs remain vulnerable to infectious diseases outbreaks. Their capacity for surveillance, early detection and response to such outbreaks is generally limited, with laboratory capacity issues and lack of human resources. Avenues for capacity strengthening should be explored by the OCTs and the related EU Member States, in collaboration with ECDC and regional public health networks where these exist.

\section{Introduction}

The term European overseas countries and territories (OCTs) refers to countries and territories that maintain specific relationships with France, the United Kingdom, the Netherlands and Denmark. OCTs are distributed all over the world and some are extremely remote and isolated (Figure 1). For instance, it takes seven days by sea from South Africa to reach Tristan da Cunha, which is a dependency of Saint (St) Helena in the South Atlantic. More than half of the 25 OCTs are located in the Caribbean region (Figure 2 ).

While OCTs are not part of the European Union (EU) they have a particular legal status vis-à-vis the EU which differs from that of any third country, and their nationals are European citizens. The OCTs are associated with the EU within the provisions of part IV of the European Community Treaty [1] and the details of this cooperation are laid down in the Overseas Association Decision of 27 November 2001 [2]. The latter will expire in December 2013 and through the Overseas Association Decision renewal, the EU and the OCTs are engaged in a process to modernise their relationship for their mutual benefit.

A major characteristic of the OCTs is their diversity in terms of size, population, natural environment, climate and resources. Territory sizes range from 47 $\mathrm{km}^{2}$ (Pitcairn) to more than 2 million $\mathrm{km}^{2}$ (Greenland) [3]. The population of permanently inhabited OCTs, ranges from 48 on Pitcairn to almost 260,000 in French Polynesia [3,4]. Other OCTs such as the British and the French Antarctic and British Indian Ocean 
territories are not permanently inhabited but only host military personnel and scientists. Most OCTs have to contend with environmental hazards such as volcanic activity, extreme weather conditions or hurricanes and tropical storms. Financial resources vary considerably among OCTs, with some OCTs heavily dependent on their related EU Member State while others are totally independent, with a high gross domestic product (GDP).

In 2008, the European Centre for Disease Prevention and Control (ECDC) commissioned an assessment of the capacity of the OCTs to prevent and control infectious diseases outbreaks [5]. The objective was to identify the needs of the OCTs in terms of communicable disease prevention and control, and to suggest activities to address such needs. This assessment was coordinated by the British Health Protection Agency, with the support of the French Institut de Veille Sanitaire, the Dutch National Institute for Public Health and the Environment, and the Greenland National Board of Health. A structured questionnaire was developed and completed by public health experts in the OCTs. The data collected were compiled into a summary report and OCT specific reports that were reviewed during a stakeholder meeting that took place in London in October 2009 [6].
This article is based on the results of this needs assessment [6]. It was updated in July 2011 and takes into consideration the latest administrative, political and epidemiological situation. It includes the most recent publically available data (from national or international sources) and the year of the source is given in the text. We present an overview of the European OCTs geography and epidemiology and briefly introduce the legal basis on which OCTs are linked to the EU and describe the surveillance and infectious disease response systems, including challenges and opportunities to build on existing capacities.

\section{Overseas country of Denmark}

\section{Overview of Greenland}

The Kingdom of Denmark is composed of Denmark, the Faroe Islands and Greenland, the latter has OCT status. Located between the Arctic Ocean and the North Atlantic Ocean, Greenland is the world's largest island and more than $80 \%$ of its surface is permanently covered with ice [3]. Greenland has an arctic climate with a monthly average temperature varying between -8 ${ }^{\circ} \mathrm{C}$ and $+8{ }^{\circ} \mathrm{C}[7]$. There are no roads connecting the 18 towns in the country [8], so all transport takes place by plane or by ship. For short distance travels, the local population uses boats, dogsleds or snowmobiles.

\section{FIGURE 1}

World map of the European overseas countries and territories, 2011

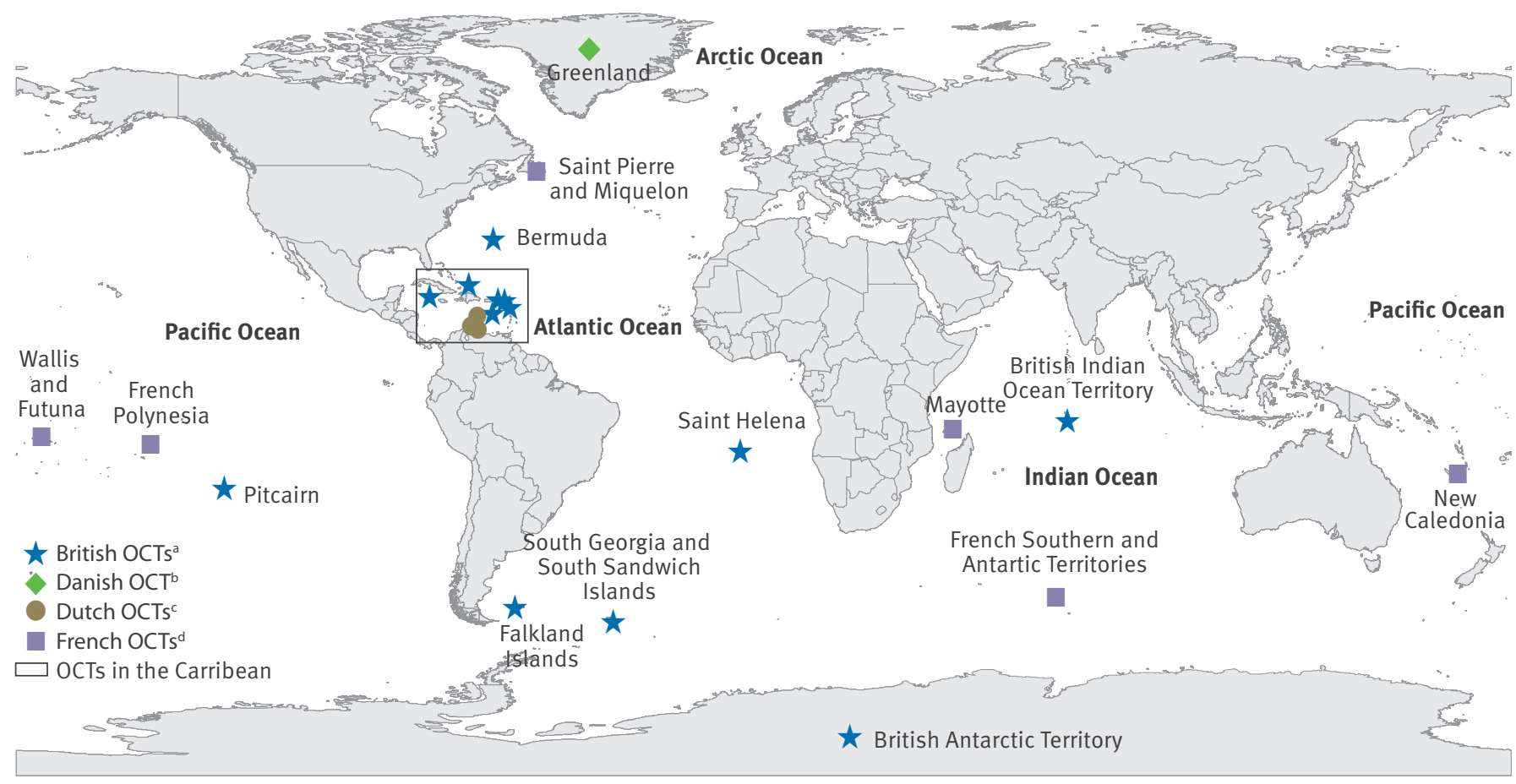

OCT: overseas countries and territories.

a British OCTs include Anguilla, Bermuda, British Antarctic Territory, British Indian Ocean Territory, British Virgin Islands, Cayman Islands, Falkland Islands, Montserrat, Pitcairn, South Georgia and South Sandwich Islands, Saint Helena, Turks and Caicos Islands.

b Danish OCT includes Greenland.

'Dutch OCTs include Aruba, Bonaire, Curacao, Saba, Sint Eustatius and Sint Maarten.

${ }^{\mathrm{d}}$ French OCTs include French Polynesia, French Southern and Antarctic Territories, Mayotte, New Caledonia, Saint Pierre and Miquelon, Wallis and Futuna. 
Greenland has 56,000 inhabitants. The population is young, with $23 \%$ aged under 15 years, $69 \%$ aged from 15 to 64 years, and $8 \%$ aged 65 years or more [8]. The population is composed of Inuit and Europeans. Greenlandic is the official language although Danish is widely used. In 2008, the GDP per capita of Greenland and Denmark were comparable with respectively EUR 23,000 and EUR 23,900 [3].

\section{Legal status of Greenland}

In the 18th century, Danes began to colonise the island and in 1953 Greenland became part of Denmark. In 1978, the Danish parliament granted Greenland selfgovernment (home rule) and in 1992, Greenland took over the responsibility for healthcare. In June 2009, Greenland moved from home rule to autonomy and took a step towards independence.

\section{Epidemiological situation}

Overall mortality rate in Greenland is 7.6 deaths per 1,000 persons per year (2008) compared to 10 per 1,000 in Denmark (2008), reflecting the differing age structure in the populations [9]. However, life expectancy at birth is 66.6 years for males and 71.6 years for females (2004-2008) which is about 10 years lower (for both sexes) than in Denmark (2008) [9]. Infant mortality is estimated around $25.3 \%$ (2008) in Greenland, compared to $3.9 \%$ (2008) in Denmark [9]. Over the past 20 years there has been a significant rise in the occurrence of cancer, cardiovascular disease, diabetes and obesity [9]. The main causes of mortality are cancer, suicide, cerebrovascular diseases and chronic pulmonary diseases. With regard to infectious diseases, Greenland has a very high prevalence of sexually transmitted infections with an incidence above 4,400 per 100,000 inhabitants for chlamydia infections (2008) and above 1,600 per 100,000 inhabitants aged above 15 years for gonorrhoea (2008) [9]. Mortality from human immunodeficiency virus/acquired immune deficiency syndrome (HIV/AIDS) is higher than in continental Europe with 1.8 deaths per 100,000 inhabitants in Greenland (2008) compared to 0.4 per 100,000 in Denmark (2008) [9]. In addition, tuberculosis is a large problem with an incidence of 120 cases per 100,000 men and 88 cases per 100,000 women (2008), compared to respectively 8 per 100,000 men and 5 per 100,000 women in Denmark (2008) [9]. During the last five years, there has been no major outbreak of infectious disease reported in Greenland [6].

\section{Surveillance and outbreak response capacity} Surveillance of communicable diseases in Greenland is carried out by the National Board of Health which is informed of all cases of infectious diseases and related deaths by the districts' healthcare authorities. All 49 notifiable diseases in the EU are also under surveillance

\section{FIGURE 2}

Map of the European overseas countries and territories in the Caribbean region, 2011

British OCTs ${ }^{\mathrm{a}}$

Dutch OCTs ${ }^{\mathrm{b}}$

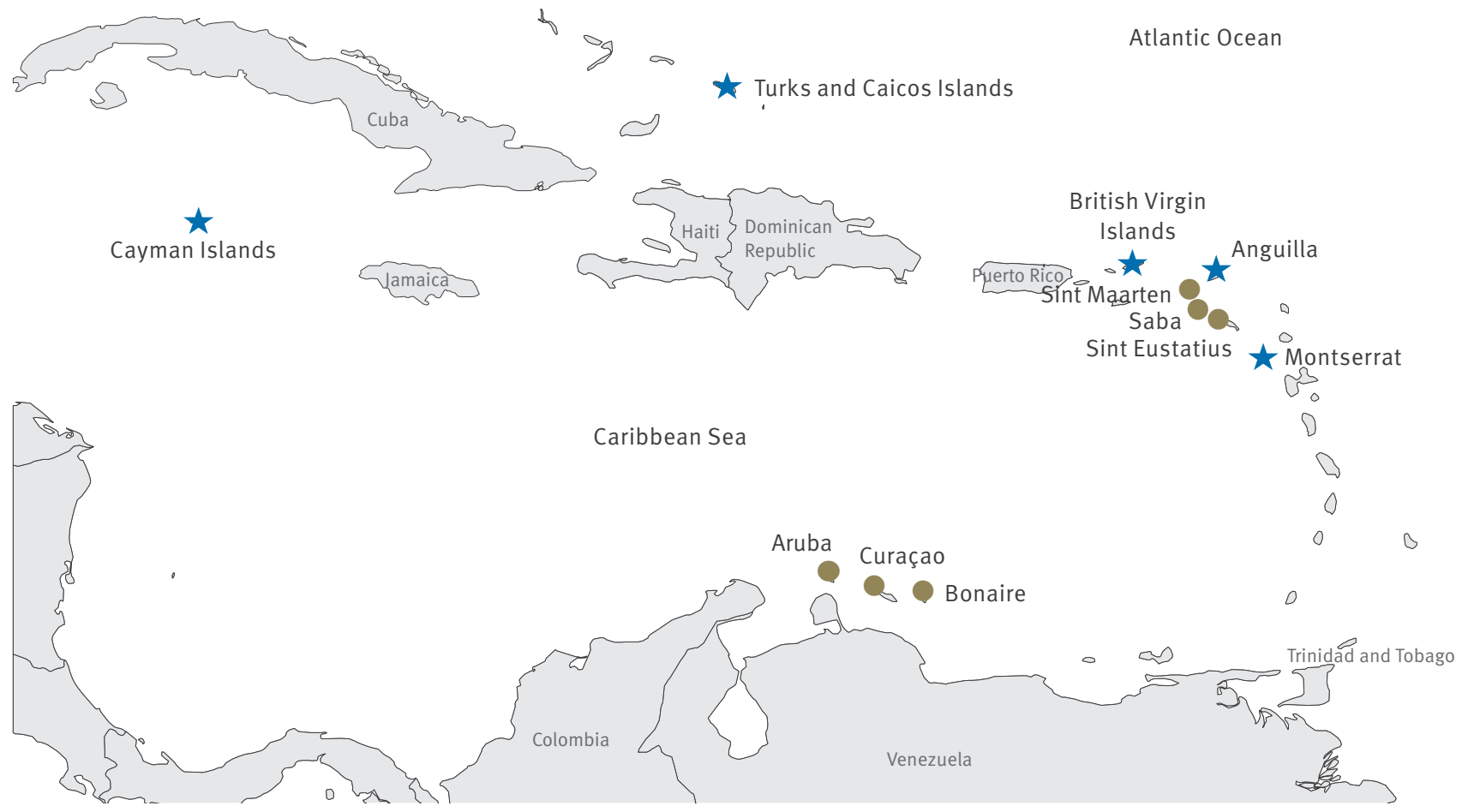

OCT: overseas countries and territories.

a Anguilla, British Virgin Islands, Cayman Islands, Montserrat, Turks and Caicos Islands.

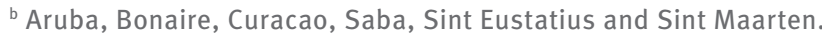


in Greenland. The National Board of Health analyses the surveillance data and reports unusual events, including outbreaks, to the Statens Serum Institut (SSI) in Denmark. In terms of risk assessment and response to infectious diseases outbreaks, the National Board of Health receives, when necessary, support from the SSI and the International Circumpolar Surveillance System (ICSS) [10].

Because of its size, the fact that the population is scattered over a large area, and the absence of roads, providing equal access to healthcare to all residents, independently of their place of residence, implies large costs for the Greenlandic healthcare system. Twelve percents of health expenditures of the country are allocated to transportation of patients and their relatives, abroad or within Greenland, and transportation of medical staff and equipment [6].

The healthcare system struggles with filling vacant positions. Most of the healthcare staff comes from abroad, resulting in a need for interpretation services and a lack of continuity.

Routine microbiological testing including tuberculosis microscopy is performed in Greenland. For further sub-typing and culture, virological and parasitological tests, samples are sent to SSI which implies additional costs and time delays.

\section{Conclusion}

Like in the EU, the main burden of diseases in Greenland is due to non-communicable diseases with an important rise in morbidity in the past 20 years. At the same time, tuberculosis and sexually transmitted infections remain a problem on the island with a level of infection much higher than that of continental EU. A surveillance system for infectious diseases is in place and Greenland can rely on Denmark and the ICSS for support in case of an outbreak of major importance.

\section{Overseas countries and territories of France}

\section{Overview of the French Overseas}

\section{Countries and Territories}

The six French OCTs consist of French Polynesia, French Southern and Antarctic Territories, New Caledonia, St Pierre and Miquelon, Wallis and Futuna and the overseas department of Mayotte.

Three of the six French OCTs are located in the Pacific region. They include French Polynesia, New Caledonia and Wallis and Futuna. With almost 260,000 inhabitants, French Polynesia is the most populated European OCT. It is composed of five archipelagos and around 118 islands of volcanic or coral origin, covering a land area of 4,200 $\mathrm{km}^{2}$ but spreads over 2,500,000 km² (equivalent to the surface of Europe) $[4,11]$. The population of New Caledonia consists of 245,580 inhabitants [4], who are unequally distributed over an archipelago with a main island where four fifths of the population live, and several smaller ones. Isolated from the rest of the world, 2,100km from New Caledonia and 2,800km from French Polynesia, Wallis and Futuna has an area of $142 \mathrm{~km}^{2}$ [12]. The territory includes two main islands, Wallis Island and Futuna Island. The resident population of Wallis and Futuna is estimated to be about 13,445 inhabitants [4].

Mayotte is an island located in the South Indian Ocean, in the Mozambique Channel. The population is estimated to be 186,500 [4] of whom one third are undocumented migrants $[13,14]$.

With some variations, the climate of the four tropical OCTs mentioned above is broadly the same: hot and humid. The rainy season lasts from November to April with high temperatures of about $25-35^{\circ} \mathrm{C}$, the cooler dry season runs from May to October with lower temperatures of around $20-25^{\circ} \mathrm{C}[11,15-17]$.

Located in the North Atlantic Ocean, St Pierre and Miquelon lies in the northern part of North America, $25 \mathrm{~km}$ south of Newfoundland (Canada). Its size is 242 $\mathrm{km}^{2}$ [12], with three main islands: St Pierre, Miquelon and Langlade. The population living in St Pierre and Miquelon is 6,000 [4]. St Pierre is the smallest island but hosts $90 \%$ of the population. The island has a temperate oceanic climate. Spring and autumn are cold and wet with mist and fog, and wind. Winters are less extreme than in Canada, with $-10^{\circ} \mathrm{C}$ to $-5^{\circ} \mathrm{C}$, and temperatures in summer are between $10{ }^{\circ} \mathrm{C}$ and $20{ }^{\circ} \mathrm{C}$ [18].

The French Southern and Antarctic Territories are a group of islands spread throughout the southern Indian Ocean without a permanent population.

GDP per capita in the French OCTs is lower compared to France. Mayotte and Wallis and Futuna have the lowest GDP per capita of with EUR 5,200 (2005) and EUR 10,100 (2008) respectively $[19,20]$. French Polynesia, New Caledonia and St Pierre and Miquelon have the highest GDP per capita with respectively EUR 17,400 (2008), EUR 24,700 and EUR 26,100 (2004) [20]. In comparison, France's GDP per capita is EUR 30,400 (2008) [20].

\section{Legal status of the French Overseas \\ Countries and Territories \\ The legal statutes of the French OCTs vary widely.}

Boasting a high level of autonomy, French Polynesia and New Caledonia have their own authorities and legislation in terms of public health and communicable diseases. In contrast to this, St Pierre and Miquelon and Wallis and Futuna are dependent on the French authorities for health related matters.

Following the 2009 Mahoran status referendum, in March 2011, the former French overseas territory of Mayotte became an overseas department as French Guyana, Guadeloupe, Martinique and Réunion. French 
laws and regulations are henceforth fully applicable. Despite the change in status of Mayotte with regard to France, Mayotte remains a European OCT with regard to EU law.

\section{Epidemiological situation}

Life expectancy at birth for both sexes is broadly comparable to that in the rest of France (78.1 years for men, 84.8 years for women) (2010) [21] with some variations, for instance it is slightly lower in Wallis and Futuna (2005-2008) and in Mayotte (2006) [22,23]. Infant mortality is estimated around 3.8\%o (2009) [24] in metropolitan France and the overseas departments other than Mayotte, where it is estimated around 13.5\% (2007) [23]. In the French OCTs (except for Mayotte) infant mortality range between 6 and 7.5\%o (2007-2011) [3,25].

As in France, non-communicable diseases represent the main burden in terms of mortality in the OCTs: cardiovascular diseases, cancer, diabetes and traumatic injuries. However, infectious diseases such as gastroenteritis, respiratory infections (including tuberculosis), sexually transmitted infections and leptospirosis are among the major causes of morbidity [6]. The population in the Pacific islands and Mayotte is also prone to epidemics of influenza, dengue and leptospirosis. Other common infectious diseases include leprosy (New Caledonia and Mayotte), brucellosis (Wallis and Futuna), filariasis (French Polynesia and Wallis and Futuna), malaria (Mayotte), chikungunya (Mayotte) [6,27-28]. Recent examples of infectious diseases outbreaks in the pacific islands are the outbreak of dengue and leptospirosis in New Caledonia, where dengue affected more than 7,000 people between February and April 2009 [29], while the outbreaks of leptospirosis affected more than 140 people during the first semester of 2009 and 82 for the first trimester of $2011[30,31]$. These territories were also heavily hit by the 2009 influenza $A\left(\mathrm{H}_{1} \mathrm{~N}_{1}\right)$ pandemic: the estimated influenzalike illness attack rates in September 2009 were $13 \%$ in French Polynesia, $18 \%$ in New Caledonia, $28 \%$ in Wallis and $38 \%$ in Futuna [32]. In 2005 to 2006, Mayotte was severely affected by an outbreak of chikungunya: in April 2006, seroprevalence of recent infection among pregnant women rose to $26 \%$ and in May 2006, the estimated attack rate was about $25 \%$ [33].

The presence of multiple mosquito vectors such as Anopheles (Mayotte), Culex or Aedes spp. poses a risk of outbreaks of arthropod-borne diseases like chikungunya, dengue, Rift Valley fever and yellow fever. In March 2011, the first autochthonous cases of chikungunya infections were reported from New Caledonia [34]. The concomitant presence of competent vectors, viruses and naïve population create the conditions for large epidemics. The chikungunya outbreak that affected Réunion in 2005 and 2006 and resulted in over 240,000 cases is a good example for this [35].

Due to its location and climate, St Pierre and Miquelon has a totally different epidemiological profile and is not currently at risk for large outbreaks of vector-borne diseases.

Surveillance and outbreak response capacity In the French OCTs, surveillance relies on mandatory notifications, reports from peripheral and central health facilities, laboratories and sentinel networks of physicians but, depending on the territories, the implementation and quality vary considerably. In French Polynesia and New Caledonia, surveillance systems include other sources of information such as monthly communicable disease records, non-specific indicators and death certificates. In French Polynesia, reporting frequency varies widely and one of the authorities' objectives is to provide more regular and organised results. In Wallis and Futuna, Mayotte and St Pierre and Miquelon, surveillance is poor. It is based on laboratory results and hospital information which are mainly focused on epidemic prone diseases.

Early warning systems rely on signals sent by physicians and analysed by health authorities but their organisation and efficiency differ between OCTs. In French Polynesia and New Caledonia, these systems have been codified. Alert units are in place to receive signals, analyse risks and react to alerts, on a $24 / 7$ basis.

The capacity of French OCTs to respond in terms of risk assessment and implementation of control measures depends on territories' size and consequently on the degree of specialisation of available staff and on the level of services provided by the different facilities (laboratories, health units etc.). In terms of preparedness, the OCTs have developed plans and measures to respond to emergencies. They have also implemented mechanisms to seek support either from mainland France (Ministry of Health, Institut de veille Sanitaire, etc.), from neighbouring countries or islands i.e. Australia in the case of New Caledonia, Réunion in the case of Mayotte and regional public health networks i.e. Pacific Public Health Surveillance Network (PPHSN) [36]. These contacts and networks were of great value in health alerts or responses, such as during the 2009 influenza $\mathrm{A}\left(\mathrm{H}_{1} \mathrm{~N}_{1}\right)$ pandemic (personal communication, Marc Gastellu-Etchegorry, 24 August 2010). Finally, although the health systems, public or private, deliver good quality care, the OCTs face some limitations due to their remote location (Wallis and Futuna, French Polynesia and to a lower extent New Caledonia), or due to their small size and lack of capacities (St Pierre and Miquelon, Mayotte and Wallis and Futuna) [6].

Both French Polynesia and New Caledonia have laboratories able to perform a large range of microbiology tests including virology. In French Polynesia, the laboratory capacities are centralised on the island of Tahiti. In addition, the islands of Utuora and Taiohae are able to perform biochemical, haematologic and bacteriological tests. Other archipelagos send their samples to Tahiti based on an existing agreement [6]. 
If a test cannot be performed in French Polynesia and New Caledonia, samples are sent either to mainland France or to the regional reference laboratory of the World Health Organization in Melbourne, Australia. In Wallis and Futuna, most basic microbiological tests are directly performed by the local laboratory. Serology is performed for influenza, dengue, HIV, viral hepatitis and other diseases of viral and bacterial origin such as brucellosis. Further laboratory tests including PCR are performed in New Caledonia and France [6].

In Mayotte, there is a laboratory that performs bacteriological, parasitological and virological tests including identification of dengue, chikungunya Rift Valley Fever, West Nile viruses and HIV. When necessary, samples are sent either to Réunion or to France [6].

On St Pierre and Miquelon there is capacity to perform basic bacteriological and parasitological tests. Virological tests are carried out in Canada. Agreements also exist with mainland France for laboratory support. The influenza $\mathrm{A}\left(\mathrm{H}_{1} \mathrm{~N}_{1}\right)$ pandemic in 2009 revealed limits to this form of collaboration principally due to the cost and organisational constrains of samples shipment [6].

\section{Conclusion}

In conclusion, the French OCTs in the Pacific region as well as Mayotte are at risk for large outbreaks of infectious diseases such as dengue, leptospirosis and chikungunya. Surveillance and response capacity to unusual events should be strengthened, especially for the smaller islands. Despite significant difference among the French OCTs in their legal status and level of autonomy, all of them receive strong support from mainland France and regional public health networks.

\section{Overseas countries and territories of the Netherlands}

\section{Overview of the Dutch Overseas \\ Countries and Territories}

The six Caribbean islands of Aruba, Bonaire, Curaçao, Saba, Sint (St) Eustatius and St Maarten together with the Netherlands form the Kingdom of the Netherlands. Aruba, Bonaire and Curaçao are located relatively close to the mainland of Venezuela. The other three islands, St Maarten, St Eustatius and Saba, lie approximately $900 \mathrm{~km}$ to the north. The climate is tropical, semiarid savannah-like with about $28{ }^{\circ} \mathrm{C}$ all year-round in the southern islands [3]. The northern islands have a tropical marine climate, with tropical storms and hurricanes between June and November and an average temperature of about $26^{\circ} \mathrm{C}$ during the hottest month of July [3]. All islands have a flat, slightly hilly landscape, except for Saba and St Eustatius which are volcanic islands for which some seismic activity has been recorded.

While tourism is the main source of income for Aruba and St Maarten, Curaçao also receives income from oil refining and the financial sector. Aruba has a GDP per capita of around EUR 16,800 (2006) [37] and Curaçao
EUR 12,000 (2004) [3]. For comparison the Netherlands has a GDP per capita of more than EUR 35,500 (2010) [38]. This has led in general to a fairly high standard of living in the Dutch OCTs. The importance of tourism as economic contributor however, can lead to extensive, protective, control measures, e.g. entry screening of all persons in Aruba during the influenza pandemic in 2009 [39].

\section{Legal status of the Dutch Overseas Countries and Territories}

The Dutch OCTs, formerly called the Netherland Antilles (NA), obtained autonomous status, within the Kingdom, for internal affairs in 1954. This included healthcare and thus infectious disease surveillance and control. In 1986, Aruba separated itself from the NA and acquired autonomous status within the Kingdom. In October 2010, a new state reform resulted in Curaçao and St Maarten obtaining an autonomous status, while the smaller islands of Bonaire, Saba and St Eustatius became 'extraordinary' municipalities of the Netherlands. The latter are henceforth subjected to the infectious disease legislation and control system in the Netherlands.

\section{Epidemiological situation}

The number of inhabitants of the former NA (Bonaire, Curacao, Saba, St Eustatius and St Maarten) is almost 200,000 (2010) [40]. The life expectancy at birth is 73.3 years for men and 80.3 years for women (2007-2009) [41] and the infant mortality rate is $9.1 \%$ (2010) [42]. The population of Aruba totals over 107,000 persons (2009) [43], with a life expectancy of 75.7 years (2011) and an infant mortality rate of $12.9 \%$ (2011) [3]. In comparison, life expectancy at birth in the Netherlands is 79.7 (2011) [3] and the infant mortality rate is $4.6 \%$ o (2011) [3].

The main causes of morbidity for both Aruba and the former NA are comparable to those of industrialised countries, and related to cancer, obesity and cardiovascular diseases. Leading causes of mortality in the Dutch OCTs are cardiovascular diseases, cerebrovascular diseases, cancer and diabetes mellitus [6]. In addition, Aruba also registers injuries, poisoning, septicaemia and acute respiratory infections as important causes of death [6].

Despite the tropical climate, communicable diseases are not a major cause of morbidity or mortality. Due to the high standard of living, the good quality of drinking water, the presence of septic tanks at household level and some sewage systems, in combination with good access to first-line healthcare providers, the Dutch islands have made the same epidemiological transition as industrialised countries and many developing countries.

During the rainy seasons, the Dutch OCTs regularly face outbreaks of dengue, despite existing control programmes for the vector Aedes aegypti [44]. For outbreak control, open water kept in cisterns is treated 
with abate, and fogging is performed in open areas. Bacillus thuringiensis israelensis (Bti) as well as biological larvicide measures are also used.

HIV infection in the former NA is relatively high with $1.3 \%$ to $2.1 \%$ prevalence in adults aged 15 to 49 yearsold (2007-2008) [45]. Among the islands of the former NA, St Maarten is the most affected with an estimated prevalence rate in adults (15-49 years-old) between $2.1 \%$ and $3.5 \%$ (2007-2008) [45]. In comparison, for the same age group, prevalence in the Netherlands ranged between $0.1 \%$ and $0.3 \%$ (2009) [46]. St Maarten as well as Curaçao embarked in the past years on an elaborate comprehensive awareness and prevention campaign for HIV [45,47].

\section{Surveillance and outbreak response capacity}

For infectious disease surveillance, the islands of the former NA implemented a syndromic surveillance system, in line with the system set up by the regional Caribbean Epidemiology Centre (CAREC) [48]. Implementation of a similar syndromic surveillance system in Aruba is planned for the end of 2011. Data collected are analysed locally and shared with CAREC for regional surveillance. Medical doctors' compliance to report cases of notifiable infectious diseases is not consistent and therefore cases are generally underreported (personal communication, Izzy Gerstenbluth, 25 June 2010). However, the small size of the islands and close connections between people facilitate early warning in case of outbreaks.

Infectious disease response on the Dutch islands is facilitated by well established disaster preparedness systems as the Dutch OCTs are vulnerable to natural disasters, for example hurricanes, and by close links between local and regional actors. Response to infectious disease incidents is, however, hampered both by lack of trained personnel on the smaller islands, as well as by the absence of non-routine microbiological facilities. The influenza $A\left(\mathrm{H}_{1} \mathrm{~N}_{1}\right)$ pandemic response in 2009 showed that the capacity of the response teams is easily overstretched (personal communication, Izzy Gerstenbluth, 25 June 2010), while microbiological confirmation by PCR performed in the Netherlands resulted in diagnostic delay.

Laboratory facilities are basic (Biosafety level 2 including basic parasitology), and diagnostic capabilities to detect new and emerging pathogens e.g. West Nile virus, chikungunya virus are not available. Tests not performed locally are referred to CAREC in Trinidad and Tobago, the Dutch National Institute of Health and Environment (RIVM) or the laboratory of the Erasmus Medical Centre in the Netherlands to where samples can be shipped within 24 hours.

The Dutch OCTs report unusual communicable diseases events to both CAREC and the RIVM which can provide support to the Dutch OCTs in case of major outbreaks. Public health law in the Dutch OCTs is currently being revised and adjustment to the International Health Regulations (IHR) 2005 (e.g. on port of entries and ship's certification) should be implemented by 2012 [49].

\section{Conclusion}

The morbidity due to communicable diseases in the Dutch OCTs is comparable to Europe, except for the regular outbreaks of dengue and the high prevalence of HIV infection, especially in St Maarten. Monitoring for new and re-emerging diseases needs to be improved and surveillance systems need to be enhanced. Laboratory facilities and human capacity development on all of the islands as well as logistic constraints need to be strengthened.

\section{Overseas countries and territories of the United Kingdom}

\section{Overview of the British Overseas \\ Countries and Territories}

The British OCTs are located all around the world; in the Caribbean: Anguilla, Bermuda, British Virgin Islands, Cayman Islands, Montserrat, Turks and Caicos Islands; in the Atlantic Ocean: Falkland Islands, Saint Helena, South Georgia and South Sandwich Islands; in the Indian Ocean: British Indian Ocean Territory; in South Pacific: Pitcairn; and in Antarctica: British Antarctic Territory.

Some are extremely isolated and among the most remote locations in the world. Their climates and terrains vary widely, and many British OCTs are subject to environmental hazards such as volcanic activity, hurricanes, tropical storms and other extreme weather conditions. Territory sizes range from $47 \mathrm{~km}^{2}$ to over $1,700,000 \mathrm{~km}^{2}$. Not all of the OCTs have permanent populations but among places with permanent inhabitants, the population ranges from 48 (2011) on Pitcairn to nearly 68,700 (2011) on Bermuda [3]. Population growth is particularly high in the Cayman Islands and the Turks and Caicos Islands, the latter having doubled its population in the past 10 years from 20,014 inhabitants in 2001 to 44,819 inhabitants in 2011 [3,50]. This population growth is partly explained by immigration: about one third of the Turks and Caicos Islands' population is made up of temporary residents, including groups of undocumented immigrants, living in conditions which make them vulnerable to communicable diseases [6].

The GDP of the OCTs also varies widely: while some have a low GDP per capita i.e. Anguilla (EUR 7,700 in 2008), Montserrat (EUR 3,400 in 2002), Turks and Caicos Islands (EUR 11,400 in 2002) and St Helena (EUR 2,900 in 1998), others i.e. Bermuda (EUR 55,600 in 2004) and Cayman Islands (EUR 35,000 in 2004) are considerably more affluent than the UK (EUR 26,800 in 2010) [3]. 
Legal status of the British Overseas

\section{Countries and Territories}

Although all the OCTs are part of United Kingdom territory, and all United Kingdom Government departments have responsibilities in relation to their support, each is self governing with its own legal framework and healthcare system.

\section{Epidemiological situation}

The main health issues for the population of the British OCTs are reported as chronic, non-communicable diseases such as diabetes, cardiovascular disease and cancer, with lifestyle factors such as smoking, obesity and alcohol consumption noted as being important contributory factors [6]. For both sexes, life expectancy is broadly comparable to that in the United Kingdom. Life expectancy at birth is 77.7 years for males and 81.9 years for females (2007-2009) [51], though it is lower in the Falkland Islands, 69 years at birth for men and 70 years for women (2008) [6]. While Anguilla, Bermuda and the Cayman Islands report an infant mortality rate lower or slightly higher than in the UK (4.6\% in 2011), the British Virgin Islands, Montserrat, St Helena and the Turks and Caicos Islands report higher infant mortality rate ranging from 12 to $16.4 \%$ (2011) [3].

In the British OCTs of the Caribbean region, the leading infectious disease causes of morbidity are HIV/AIDS, respiratory infections (e.g. influenza) and gastrointestinal infections (e.g. salmonellosis, norovirus infections) [6]. Major epidemiological issues in the region include a high estimated prevalence of people living with HIV in the Turks and Caicos (1,640 cases per 100,000 inhabitants in 2005) $[52,53]$ and a high prevalence of tuberculosis in Montserrat (474/100,000 in 2009) and the British Virgin Islands (94/100,000 in 2009) [54]. In comparison, the HIV and tuberculosis prevalence estimated in the United Kingdom are respectively 139 (2010) and 15 (2009) cases per 100,000 inhabitants [54-56].

In the British OCTs, no large outbreaks of infectious diseases have been reported in the past years, apart from the influenza $A\left(\mathrm{H}_{1} \mathrm{~N}_{1}\right)$ pandemic in 2009 [6]. Despite, the presence of Aedes aegypti and regular reports of imported dengue fever cases in the British OCTs of the Caribbean region, and the occurrence of dengue outbreaks in other Caribbean islands, no major dengue outbreak has occurred in the Caribbean British OCTs in decades [6].

\section{Surveillance and outbreak response capacity}

OCTs vary in terms of whether they have any formal surveillance and/or early warning systems. For small islands where the incidence of infectious disease is low and communication within the community rapid, like in Pitcairn and in the St Helena's dependencies of Tristan da Cunha and Ascension islands, there is no need for a formal surveillance system. In the British OCTs of the Caribbean region, the local public health authorities monitor infectious diseases via a syndromic surveillance system developed by CAREC and supported by clinical and laboratory services. Collected data are analysed on-site or sent directly to CAREC for further analysis at the regional level. The main challenges that OCTs face in relation to surveillance are related to data management systems, epidemiological expertise and clinician/microbiological involvement, and most suffer from issues of expertise continuity [6].

Laboratory services also vary considerably. Pitcairn and Tristan da Cunha have no laboratory facilities at all. All other British OCTs may have adequate services for most locally prevalent diseases, but limited services for a wider range of diseases. Even OCTs with good basic microbiological services have to send samples abroad for more specialised testing, and this incurs delays and costs, even where regional facilities exist. Once more, the British OCTs of the Caribbean region receive laboratory support directly from CAREC. Additionally, some of the British Caribbean OCTs have specific agreements for testing with private laboratories abroad. For instance, the British Virgin Islands and the Cayman Islands send their samples for further testing to CAREC but also occasionally to a private laboratory in Puerto Rico for the British Virgin Islands or to Miami for the Cayman Islands [6]. For geographically isolated places viability of samples after transit is an issue. For virology testing other than HIV and hepatitis viruses, the Falkland Islands send their sample to the United Kingdom usually on a weekly basis. Results are generally provided within two to four weeks [6]. Because of difficult political relations with Argentina, the Falkland Islands' participation in regional surveillance and control activities, including joining the PanAmerican Health Organization, is restricted. As part of PPHSN, Pitcairn receives support from the network but has also established in parallel contract with a private laboratory in New Zealand. A low incidence of infectious disease means that laboratory skills may be hard to maintain, quality is sometimes more difficult to assure, and clinicians may lack the necessary experience to collect correct samples. Of particular concern is the ability to diagnose serious or unusual illness.

The capacity of the British OCTs to assess the risk and respond to infectious diseases outbreaks is different from one island to the other, the main determinant being the availability of human and technical resources. When resources are scarce, access to external support is a key component of the assessment and response. British OCTs of the Caribbean region can rely on CAREC expertise and support. For instance, following the detection of few autochthonous malaria cases in the Cayman Islands in the late 9os, CAREC provided technical support to the local authorities to contain this outbreak [6]. A more recent example is that the Turks and Caicos Islands received immediate support from CAREC and the Department for International Development (DFID) in the UK to strengthen their preparedness and response capacity with regard to the cholera outbreak that started in the neighbouring countries of Haiti and the Dominican Republic respectively 
in October and November 2010 (personal communication, Dilys Morgan, 3 December 2010). Where there is no regional network, assistance may come from the United Kingdom, and or neighbouring countries. For example, the Falkland Islands may receive assistance from the United Kingdom and St Helena may request support from South Africa and or the United Kingdom.

Some OCTs, such as Anguilla, the British Virgin Islands, the Cayman Islands, Montserrat, the Turks and Caicos Islands and the Falkland Islands have specific response teams and plans (including communications strategies) to deal with outbreaks [6]. Because of its small size and limited capacity, Pitcairn does not have formal response team and plan and has very little capacity to respond to a crisis caused by a severe epidemic disease.

Ability to sustain a response to outbreaks is a serious concern. With resources dedicated to their control limited and declining, OCTs may be left vulnerable to sudden changes in their local infectious disease epidemiology and health services could quickly become overwhelmed by unusual incidence of illness.

\section{Conclusion}

To conclude, for many British OCTs, limited diagnostic capability or systematic collection of information means that their true burden of infectious diseases is difficult to quantify, though most report a low burden. Most OCTs suffer health service limitations related to their size; with small populations most can only provide a narrow range of domestic services, with specialised services often being provided through referral abroad. Similarly public health systems are variable in their size and level of expertise and while some OCTs receive excellent support from regional networks, others do not have this opportunity.

\section{Conclusion}

This overview of the 25 European OCTs underlines their heterogeneity in terms of epidemiological profiles, legal relationships with their related EU Member State, and capacity for surveillance and response to infectious disease outbreaks. Despite marked differences, the European OCTs share some common features such as the fact that non-communicable diseases represent the main burden of disease. However, since the general capacity for surveillance and diagnosis in the OCTs is limited, it is difficult to quantify the true burden of infectious diseases.

Globally, infectious diseases of concern to the OCTs are gastrointestinal diseases, respiratory infections, tuberculosis, sexually transmitted diseases including HIV/AIDS, leprosy, and for OCTs located in the tropics, leptospirosis and vector-borne diseases, in particular dengue. Vulnerability of the OCTs' population towards outbreaks of infectious diseases is due to a combination of, among others, the prevalence of chronic diseases that may increase the susceptibility to infections, of a lack of immunity to newly introduced pathogens and of the presence of competent disease vectors. Because many OCTs receive a high number of tourists each year, and some also migrant workers, they are potentially exposed to the introduction of infectious diseases into their territory.

Laboratory capacity and human resource availability are common limitations identified for the surveillance, early warning and response to infectious disease outbreaks. Most of the OCTs suffer from limitations in the provision of health services and face logistic challenges as a result of their relative isolation.

Some OCTs can rely on the support of regional public health networks such as in the Caribbean (CAREC), the Pacific regions (PPHSN) and in Greenland (ICSS). Regional networks provide assistance in preparedness, surveillance, early detection and response to communicable and non-communicable diseases. For the most remote OCTs that do not have the opportunity to join a regional network, collaboration with neighbouring OCTs or countries can be of considerable value. Support is also provided by the related EU Member State.

Actions to strengthen preparedness and response capacity to infectious disease should build on existing structures and should focus on unusual events. Capacity building should target the most important issues identified by the OCTs. General preparedness and response capacity strengthening in the OCTs should be further developed and implemented by the OCTs and the related EU Member States and in close collaboration with regional networks where these exist. In this process, ECDC could be a valuable partner.

\section{Acknowledgements}

This article is based on the final report of the call for tender 'Assessment of the needs of the European Overseas Territories' (ref. 0J/2008/08/12-PROC/2008/027) launched by ECDC in 2008 . The study was performed by the Health Protection Agency (United Kingdom) in collaboration with the Institut de Veille Sanitaire (France), the National Institute for Public Health and the Environment (the Netherlands) and the National Board of Health (Greenland). The authors would like to thank the many representatives of the European Overseas Territories who contributed to this study and the following persons: C. Anderson, C. Bachelard, C. Bates, J. Cann, P. Cardon, R. Carter, J.A. Course, S. Davenport, A.M. De Montera, O. Dipeoluo, P. Godefroy, P. Guillaumot, G. Haringhuizen, S. Koolman, H.P. Mallet, R. McKee, L. Morisse, L. Peto, I. Potter, L. Robinson, J. Rogers, Z. Townely, H. van den Kerkhof, C. van der Merwe, J. Wilkinson, A. Wonner, J. Yeadon, G. Young and H. Zeller.

\section{References}

1. Member States of the European Union. Consolidated versions of the Treaty on European Union and the Treaty on the

Functioning of the European Union. Official Journal of the European Union 9.5.2008 C 115/47. 2008. Available from: http://eur-lex.europa.eu/LexUriServ/LexUriServ.do?uri=0J:C:2 008:115:0047:0199:EN:PDF 
2. Council of the European Union. Overseas Association Decision. Official Journal of the European Communities; 30 Nov 2001. L314/1. Available from: http://eur-lex.europa.eu/LexUriServ/ LexUriServ.do?uri=0J:L:2001:314:0001:0077:EN:PDF

3. Central Intelligence Agency (CIA). The world factbook Washington: CIA. [Accessed 12 Mar 2011]. Available from: https://www.cia.gov/library/publications/the-world-factbook/ index.html

4. Institut national de la statistique et des études économiques (INSEE). Population des collectivités d'outre-mer, de Nouvelle-Calédonie et de Polynésie française [Population of Overseas Countries and Territories of New Caledonia and French Polynesia]. [Accessed 10 Apr 2011]. French. Available from: http://www.insee.fr/fr/themes/tableau. asp?ref id=CMRnono2144

5. European Centre for Disease Prevention and Control (ECDC). Call for tender: Assessment of the needs of the European Overseas Territories. Stockholm; 2008. 0J/2008/08/12PROC/2008/027. Available from: http://www.ecdc.europa.eu/ en/aboutus/calls/Procurement $\% 20$ Related\%20Documents/ PROC_2008_027_TS_Overseas\%20Territories_final_extended. pdf

6. European Centre for Disease Prevention and Control (ECDC). Assessment of the needs of European Overseas Territories. 2009. Stockholm: ECDC. Forthcoming.

7. Climate and Temperature Information. [Accessed 11 Mar 2011]. Available from: http://www.climatetemp.info/greenland/

8. Statistics Greenland (Stat.gl). Greenland in figures 2010. Nuuk; 2010. [Accessed 10 Jul 2011]. Available from: http:// www.stat.gl/LinkClick.aspx?link=Greenland+in+Figures\%2fG IF_2010.pdf

9. Nordic Medico-Statistical Committee (NOMESCO), Health Statistics in the Nordic Countries with data from 2008. Copenhagen: NOMESCO; 2010. Available from: http://nomescoeng.nom-nos.dk/filer/publikationer/Helsestatistik2010.pdf

10. Parkinson AJ, Butler JC. Prevention and Control of Emerging Infectious Diseases in the Arctic: Establishing an International Circumpolar Surveillance System. EpiNorth. 18 Nov 2004. [Accessed 10 Jul 2011]. Available from:http://www.epinorth. org/eway/default.aspx?pid=230\&trg=Area_5268\&MainArea_5 $260=5263: 0: 15,2946: 1: 0: 0::: 0: 0 \& A r e a-5263=5268: 44984:: 1: 5$ 264:1:::0:0\&Area_5268=5273:44863::1:5266:3:::0:0

11. Ministère de l'intérieur, de l'outre mer, des collectivités territoriales et de l'immigration. Présentation - Polynésie française [Presentation French Polynesia]. [Accessed 15 Mar 2011]. French. Available from: http://www.outre-mer.gouv. $\mathrm{fr} /$ ?presentation-polynesie-francaise.html

12. Institut national de la statistique et des études économiques (INSEE). Subdivisions, superficie et population de la République française [Subdivisions, area and population of the French Republic]. 2006: INSEE. [Accessed 20 Mar 2011]. French. Available from: http://www.insee.fr/fr/themes/tableau. asp?ref_id=nattefo1209

13. Hopquin B, Canavate L. Mayotte moves to modernity. Guardian Weekly; 19 Apr 2011. Press release. Available from: http://www.guardian.co.uk/world/2011/apr/19/ mayotte-votes-modernity-france-hopquin

14. Préfecture de Mayotte. Population [Population]. [Accessed 20 May 2011]. French. Available from: http://www.mayotte. pref.gouv.fr/workspaces/administrations/decouvrir_mayotte/ population/view

15. Ministère de l'intérieur, de l'outre mer, des collectivités territoriales et de l'immigration. Présentation - Wallis et Futuna [Presentation - Wallis and Futuna]. [Accessed 15 Mar 2011]. French. Available from: http://www.outre-mer.gouv.fr/?-walliset-futuna.html

16. Ministère de l'intérieur, de l'outre mer, des collectivités territoriales et de l'immigration. Présentation - Nouvelle Calédonie [Presentation - New Caledonia]. [Accessed 15 Mar 2011]. French. Available from: http://www. outre-mer.gouv.fr/?presentation-nouvelle-caledonie. html\&artpage=1\#outil_sommaire_1

17. Ministère de l'intérieur, de l'outre mer, des collectivités territoriales et de l'immigration. Présentation - Mayotte [Presentation - Mayotte]: [Accessed 11 May 2011]. French. Available from: http://www.outre-mer.gouv.fr/?presentationmayotte.html

18. Ministère de l'intérieur, de l'outre mer, des collectivités territoriales et de l'immigration. Présentation - Saint-Pierreet-Miquelon [Presentation - Saint Pierre and Miquelon]. [Accessed 15 Mar 2011]. French. Available from: http://www. outre-mer.gouv.fr/?presentation-saint-pierre-et-miquelon.html
19. Institut national de la statistique er des études économiques. Comptes économiques rapides pour l'Outre-mer (CEROM). Mutations et évolutions de l'économie mahoraise à la veille de la départementalisation [Mutations and changes of Mayotte's economy on the eve of the departmentalization]. French. [Accessed 10 Jul 2011]. Available from http://insee.fr/fr/ themes/document.asp?reg_id=27\&ref_id=17339

20. Institut national de la statistique et des études économiques (INSEE). Une économie tertiarisée encore loin du niveau de richesse national [Tertiarised economy still far from the level of national wealth]. French. [Accessed 10 Jul 2011]. Available from: http://www.insee.fr/fr/insee_regions/guadeloupe/themes/ etudes_detaillees/diag971cesr/diag971CESR_06.pdf

21. Institut national de la statistique et des études économiques (INSEE). Evolution de l'espérance de vie à divers âges [Evolution of life expectancy at various ages]. French. [Accessed 16 Mar 2011]. Available from: http://www.insee.fr/fr/ themes/tableau.asp?reg_id=o\&ref_id=NATnono2229

22. Institut national de la statistique et des études économiques (INSEE). Recensement de la population à Wallis et Futuna 2008. [Population census in Wallis and Futuna]. [Accessed 20 Mar 2011]. French. Available from: http://www.insee.fr/fr/ffc/ ipweb/ip1251/ip1251.pdf

23. Institut national de la statistique et des études économiques (INSEE). Mortalité - Espérance de vie - Mayotte 2010 [Mortality - Life Expectancy - Mayotte 2010]. [Accessed 15 Mar2011]. French. Available from: http://www.insee.fr/fr/insee_regions/ mayotte/themes/dossiers/tem/tem_2-6-mortalite-vie.pdf

24. Institut national de la statistique et des études économiques (INSEE). Espérance de vie - Mortalité 2010 [Life expectancy - Mortality 2010]. [Accessed 20 Mar 2011]. French. Available from: http://www.insee.fr/fr/ffc/tef/tef2010/T10Fo35/T10Fo35. pdf

25. Institut de la statistique de la Polynésie française. 2009 [Accessed 17 Jul 2009]. Available from: http://www.ispf.pf/ ISPF/Chiffres/Populat/IndPop.aspx

26. Institut de la Statistique et des études économiques (INSEE). Tableaux de l’Économie Calédonienne, Population-Société [New Caledonia Facts and Figures, Population - Society]. [Accessed 25 Mar 2011]. French. Available from: http://www.itsee.nc/tec/ popsociete/popumortaliteespvie.html

27. The World Health Organization Regional Office for the Western Pacific (WPRO). Health situation and trend, Wallis and Futuna. 2008. Manila: WPRO. [Accessed 20 Mar 2011]. Available from: http://www.wpro.who.int/countries/2008/waf/health_ situation.htm

28. Institut de veille sanitaire (InVS). Chikungunya: circulation active dans le sud ouest océan Indien [Chikungunya: active circulation in the southwest Indian Ocean]. Point épidémiologique 2011; 16. [Accessed 15 Apr 2011]. French. Available from: http://www.invs.sante.fr/regions/reunion mayotte/pe_rm_chik_150411.pdf

29. La direction des affaires sanitaires et sociales de la NouvelleCalédonie. Thèmes de santé - La dengue [Health themes - Dengue]. [Accessed 20 Mar 2011]. French. Available from: http://www.dass.gouv.nc/portal/page/portal/dass/sante/ themes_sante/dengue

30. La direction des affaires sanitaires et sociales de la NouvelleCalédonie. Situation sanitaire en Nouvelle Calédonie, Etat de santé: La leptospirose. 2009. [Health situation in New Caledonia, State Health: Leptospirosis. 2009]. [Accessed 20 Mar 2011]. French. Available from: http://www.dass.gouv.nc/ portal/page/portal/dass/librairie/fichiers/14120021.PDF

31. La direction des affaires sanitaires et sociales de la NouvelleCalédonie. Thèmes de santé - La leptospirose [Health themes Leptospirosis]. [Accessed 20 Mar 2011]. French. Available from: http://www.dass.gouv.nc/portal/page/portal/dass/sante/ themes_sante/leptospirose

32. La Ruche G, Tarantola A, Barboza P, Vaillant L, Gueguen J, Gastellu et al. The 2009 pandemic $\mathrm{H}_{1} \mathrm{~N}_{1}$ influenza and indigenous populations of the Americas and the Pacific. Euro Surveill. 2009;14(42):pii=19366. Available from: http://www. eurosurveillance.org/ViewArticle.aspx?Articleld=19366

33. Sissoko D, Malvy D, Giry C, Delmas G, Paquet C, Gabrie P et al. Outbreak of Chikungunya fever in Mayotte, Comoros archipelago, 2005-2006. Trans R Soc Trop Med Hyg. 2008;102(8):780-6.

34. La direction des affaires sanitaires et sociales de la NouvelleCalédonie. Thèmes de santé - Le chikungunya [Health themes chikungunya]. [Accessed 20 Mar 2011]. French. Available from: http://www.dass.gouv.nc/portal/page/portal/dass/sante/ themes sante/Chikungunya 
35. Renault P, Solet JL, Sissoko D, Balleydier E, Larrieu S, Filleul L et al. A Major Epidemic of Chikungunya Virus Infection on Réunion Island, France, 2005-2006. Am J Trop Med Hyg. 2007;77(4): p. 727-31. Available from: http://www.ajtmh.org/ content $/ 77 / 4 / 727$.long

36. Pacific Public Health Surveillance Network (PPHSN). Outbreak preparedness and control. [cited 10 Jul 2011]; Available from: http://www.spc.int/phs/PPHSN/Outbreak/ PreparednessAndControl.htm

37. Table Gross Domestic Product 2000-2006 Central Bureau of Statistics of Aruba. [Accessed 11 Mar 2011]. Available from http://www.cbs.aw/cbs/manageDocument. do?dispatch $=$ view\&id $=1218$

38. International Monetary Fund (IMF). Netherlands: Gross domestic product - World Economic Outlook Database, October 2010. Washington: IMF; 2010. [Accessed 15 Apr 2011]; Available from: http://www.imf.org/external/pubs/ft/weo/2010/02/ weodata/weorept.aspx?pr.x $=20 \&$ pr.y $=13 \& s y=2008 \& e y=2010 \&$ $\mathrm{scsm}=1 \& \mathrm{ssd}=1 \& \mathrm{sort}=$ country $\& \mathrm{ds}=. \& \mathrm{br}=1 \& \mathrm{c}=138 \& \mathrm{~s}=\mathrm{NGDP} \mathrm{R}$ $\% 2$ CNGDP RPCH\%2CNGDP\%2CNGDPD \%2CNGDPRPC \%2CNGDP PC\%2CNGDPDPC \%2CPPPGDP\%2CPPPPC\& grp=0\&a=

39. Aruba Official Tourism Website. Swine Flu Information. 19 June 2009. Available from: http://www.aruba.com/ Explorethelsland/Travellnfo/swine_flu_information.aspx

40. Central Bureau of Statistics of the Netherlands Antilles. Population of the Netherlands Antilles 1998-2010. [Accessed 18 Jul 2011]. Available from: http://www.cbs.an/population/ population_b1.html

41. Central Bureau of Statistics of the Netherlands Antilles. Life expectancy of the population of the Netherlands Antilles by age and sex 2007-2009. [Accessed 18 Jul 2011]. Availble from: http://www.cbs.an/population/population_b13.html

42. IndexMundi. Netherlands Antilles Infant mortality rate. 2010. [Accessed 10 Jul 2011]. Available from http://www.indexmundi. com/netherlands_antilles/infant_mortality_rate.html

43. Central Bureau of Statistics of Aruba. Quarterly Demographic Bulletin. 4th quarter 2009, Aruba; 2009. Available from: http:// www.cbs.aw $/ \mathrm{cbs} / \mathrm{readBlob} . \mathrm{do}$ ?id $=3180$

44. Medlock JM, Schaffner F, Fontenille D. Invasive mosquitoes in the European associate continental and overseas territories. Stockholm: European Centre for Disease Prevention and Control; 31 Jan 2010. [Accessed 22 Apr 2011]. Available from: http://ecdc.europa.eu/en/activities/sciadvice/Lists/ECDC\%20 Reviews/ECDC DispForm.aspx?List $=512 \mathrm{ff} 74 \mathrm{f} \% 2 \mathrm{D} 77 \mathrm{~d} 4 \% 2 \mathrm{D} 4 \mathrm{ad}$ $8 \% 2 \mathrm{Db} 6 \mathrm{~d} 6 \% 2 \mathrm{Dbfof} 23083 \mathrm{f} 30$ \&ID $=762$ \& RootFolder $=\% 2$ Fen $\% 2 \mathrm{~F}$ activities \%2Fsciadvice \%2FLists\%2FECDC\%20Reviews

45. Hermanides G, Gerstenbluth I. Presentation: HIV epidemic in the Caribbean. 2008 [Accessed 10 Jul 2011]. Available from: http://www.healthefoundation.eu/blobs/hiv/Epidemiology_1. pdf

46. Joint United Nations Programme on HIV/AIDS (UNAIDS). The Netherlands: HIV and AIDS estimates. 2009. [Accessed 10 Jul 2011]. Available from: http://www.unaids.org/en/ regionscountries/countries/netherlands/

47. Lourents NT, Gerstenbluth I, HIV/AIDS surveillance Netherlands Antilles 1985-2007. (Epidemiology \& Research Unit, Medical and Public Health Service of Curacao, 2008).

48. Caribbean Epidemiology Centre (CAREC). [Accessed 10 Jul 2011]. Available from: http://www.carec.org/

49. World Health Organization (WHO). International Health Regulations (2005). Geneva: WHO; 2005. Available from: http://whqlibdoc.who.int/publications/2008/9789241580410_ eng.pdf

50. Statoids.com [Internet]. Turks and Caicos Islands. [Accessed 20 Jul 2011]. Available from: http://www.statoids.com/utc.html

51. Office for National Statistics. Life expectancy at birth, United Kingdom. 2009. [Accessed 22 Apr 2011]. Available from: http:// www.statistics.gov.uk/cci/nugget.asp?id=168

52. Pan-American Health Organization (PAHO). Perfil nacional de género, salud y desarrollo. Turks and Caicos Islands. [Accessed 10 Jul 2011]. Available from: http://www.paho.org/ cdmedia/ge_cp/TurksCaicos.html

53. Turks and Caicos National AIDS Program. Impact of HIV/AIDS in Turks and Caicos 2005. [Accessed 22 Apr 2011]. Available from: http://www.tcinationalaidsprogram.com/go/en/basics.html

54. U.S. Global Health Policy. People Living with TB per 100,000 Population 2009. [Accessed 22 Apr 2011]. Available from: http://www.globalhealthfacts.org/topic.jsp?i=17\&dsp=c

55. Health Protection Agency (HPA). HIV in the United Kingdom: 2010 Report. London: HPA; Nov 2010. [Accessed 14 Jul 2011]. Available from: http://www.hpa.org.uk/web/ HPAweb\&HPAwebStandard/HPAweb_C/1287145264558
56. Office for National Statistics, United Kingdom. Population: by gender and age, mid-2010. [Accessed 14 Jul 2011]. Available from: http://www.statistics.gov.uk/cci/nugget.asp?id=6. 